\title{
Stand-up in Estonia: From Soviet estrada to Comedy Estonia ${ }^{1}$
}

\author{
Liisi Laineste
}

\begin{abstract}
The article describes stand-up comedy in Estonia in relation to the local history of the genre. The aim is to cast light upon how the cultural context, but also the performer and audience interaction, works in achieving popularity of comic performance. The figure of a comedian as a "negative exemplar", as described by Lawrence Mintz in 1985, provides an excellent entrance point into discussing the different degrees of status of the genre in both the Soviet period and recent years.

Two periods in Estonian history - totalitarian Soviet time and democratic present time - are ruler-investigation. In the Soviet time, public shows and recordings of estrada performances were highly valued among the audiences, providing commentary on the shortcomings of the regime and daily life in a seemingly innocent manner. The topics and popularity of the most iconic of these performances are analysed side by side with the repertoire of comedians from Comedy Estonia. Comedy Estonia, a recent importer of Anglo-American tradition of stand-up in Estonia, has a devoted audience and established topics, but these differ significantly from the Soviet predecessor, that of estrada. Through a historically situated analysis, it is possible to describe the adoption of traditions (and texts within it) in a meaningful way, so that foreign becomes native and starts functioning as an aspect of collective identity, be it on the level of the entire nation or just a group of fans.

The empirical part of the study presents material from both periods, referring comparatively to some legendary comic texts from the Soviet period and routines of Comedy Estonia comedians. The main focus of the analysis is on the topics and targets that are prevalent in these very distinctive periods and consequently on the popularity of the different "stages" of local Estonian stand-up.
\end{abstract}

Keywords: estrada, stand-up comedy, audience, "negative exemplar", history of stand-up

\footnotetext{
1 The research was supported by ETF8149.
} 


\section{Introduction}

Humour is a widely global phenomenon, but its expressions vary across nations and countries. Stand-up, the history of which dates back to vaudeville in the United States and music hall performances in Great Britain, or even to the comic lectures of Mark Twain back in 1856 (Stebbins 1990: 7), is not an isolated genre either, but has been undergoing constant change according to the need to adjust to audiences at different times and in different countries. That is why it is a largely futile attempt to describe a local stand-up scene without considering its early predecessors and present-day outside influences.

The onset of the Internet era has increased the availability of comic texts and performances that may have been previously known only locally inside linguistic or geopolitical borders. Nowadays, the younger generation worldwide has access to the abundant English-language stand-up videos in YouTube and other sources. They often use it as the starting point for getting acquainted with the genre. Browsing through the countless recordings of legendary and not so legendary comedians presented side by side, the global audience formulates a lay definition of stand-up that most likely stems from the Anglo-American tradition. This is what the generation raised on YouTube clips will be expecting from the local performers as well.

Although cultures and contexts differ, the role of the comedian can be described as that of a cultural mediator and anthropologist (Mintz 1985: 73; Koziski 1997). Stand-up comedians express their thoughts about the surrounding social reality, and in doing so, create a space to channel or highlight feelings the audience wishes to express (Purcell et al. 2010: 377). In a few cases, they provide routines which, when having become popular, can enter the field of shared cultural experiences and will later be quoted as such in everyday communication between community members. This can on rare occasions extend outside the community, for example through sketches that comment on some globally relevant events or scandals like 9/11, Mohammad cartoons and the like. In achieving this, a glimpse of the evolving global stand-up scene can be attained, where both the performer and the audience are familiar with the topic and resonate with the way the issue is tackled. But more often than not, such global commentaries are bound to fail - the bigger audience, the more conflicting opinions, and in these circumstances, it is very difficult to bring a sharp joke onto stage without meeting at least some resistance. That is why comedians have to adjust their material to the specific societal context at any time, and particularly in the era of globalisation that we are living in now. Without flexibility, both in terms of form and content of the genre, the comedian is lost. 
Mintz (1985) also describes the stand-up comedian through the notion of a "negative exemplar". The marginal status of the performer helps the audience to give a comic license to mock, attack and utter the unsayable. The concept is relevant to analysing the popularity of the comedians of the Estonian estrada stage as well as present-day stand-up in Estonia because the personas of these actors are always from the periphery. It was easier to hide the subversive statements behind the lines of a society's stigmatised member - bringing forth the vices of the society was not only allowed during the Soviet period; it was a political prescription. After the status of a comedian (or, for that matter, the genre of stand-up on the whole) has been established, similar interests and tastes of the public contribute to the emergence of a devoted audience. The energy and group identification, the determining factors in the creation of a truly social experience of a stand-up event, may even overrun the importance of topics.

The article will describe a relatively new phenomenon in Estonia, that of standup comedy, in relation to the local history of the genre. We will first present a social and cultural background of Estonian comic stage shows, first and foremost the Soviet estrada, to account for the history of the genre in Estonia. The section will also give an overview of post-socialist trends in the genre, above all of the stand-up movement called Comedy Estonia.

Two periods in Estonian history - totalitarian Soviet time and democratic present time - are under investigation. These very diverse backgrounds are similar in that they both have employed and integrated impulses and influences from a more prominent culture (Russian and Anglo-American, respectively), but the outcomes of that differ, and it is worthwhile to study in which way.

The empirical part of the study will present material from both periods, referring comparatively to some legendary comic texts from the Soviet period side by side with the repertoire of comedians from Comedy Estonia. The analysis concentrates on the topics and targets that are prevalent in these very distinctive periods.

The focus is on adopting traditions (and texts within it) in a meaningful way, in the process of which foreign becomes native and starts functioning as an aspect of collective identity, be it on the level of the entire nation or just a group of fans. 


\section{History of stand-up in Estonia}

Due to a number of reasons, e.g. geographical smallness, frequent foreign invasions and openness to outside influences, humour in Estonia (among other areas of culture) has also been shaped by the most prominent contact with representatives of other nation(s) during different historical periods. The early beginnings of theatre where stand-up has its roots were presided by German influences in Estonia - regardless of belonging to the Russian Empire, Estonia retained a strong Baltic German elite. Although the early Estonian comedy stage did not share the political sharpness of a German cabaret (Jelavich 1996: 10), it blended some similar elements. For example, towards the end of the 1930s, the German national socialist comedy movement Kraft durch Freude ('Puhkus ja elurõóm') was represented in Estonia. This was a heyday for amateur directors and actors to stage and play in burlesques or farces; they also started to perform solo in shows or tours in-between other entertainment acts. Some of them even published parts of their repertoire, which bore resemblance to modern stand-up (e.g. in the form of one-liners as in Trilljärv 1919: 72-77). The first years of the Estonian republic (1920s) witnessed the birth of professional theatre in Tallinn. On the one hand, this meant that actors strived to play in more serious plays, but on the other hand the need for staged burlesque-type acts strongly persisted. Professionalism rose among actors after the Tallinn Conservatory opened the State Drama School in 1938.

The next distinctive phase in the developmental timeline in Estonia would above all include the genre called estrada, which was introduced after the first decade of the Soviet rule in the 1960s. The term entered the Estonian lexicon via its Soviet use; the phenomenon itself remained firmly rooted until the end of the Soviet era. Estrada, often translated as a variety show, refers to a show that combines a broad rubric of entertainment (music, dance and performing arts; see Mesropova 2008). Derived from Spanish, Estrado ("small stage"), it was opposed to a "big" or classical stage, thus meaning something more alternative in style. It is very close to stand-up in terms of the personality, immediate presence and interaction with the audience (three aspects identified by Double 2005: 19), see also below.

After hectic developments in the comedy scene throughout the first decade of regained independence in the 1990 s, Estonians were entertained by couplets (at times political) performed by bands like Kuldne Trio, actors performing shows of post-Soviet estrada on summer tours around the country and suit the needs of all age, income and education groups (Vana Baskini teater: Prügikast ('Dustbin')), Kreisiraadio on the radio (also on summer tours), and sketch comedians on the TV screen (e.g. Henrik Normann). No real stand-up shows to 
replace the huge estrada industry of the Soviet period popped up, which partly contributed to the discussions of humour becoming extinct after the communist regime had ended. In 2010 though, a team called Comedy Estonia gathered comedy enthusiasts of mostly non-Estonian origin (from USA and Australia) to organise regular English-language stand-up events. The leaders of the movement have indicated in interviews that they are aware of their predecessors, i.e. the estrada, labeling it as "one-man theatre", but see a clear difference in stating that "[There was] no stand-up in the American/British sense. [...] It was our goal to bring the international style to Estonia where it is one person writing his/her own material and standing on the stage." (interview with Louis Zezeran, 22.02.2012). From there on, other ventures of stand-up genre have also evolved, e.g. the popular Kinoteater created by a handful of drama students, Komeediklubi importing British stand-up comedians, or the channel MiinusMiljon on YouTube.

\section{Estrada and stand-up: Common features}

Despite Loius Zezeran's insight, almost all features of estrada shows respond to the core traits of Anglo-American stand-up. In terms of personality (Double 2005), an estrada show actor is usually alone, and facing the audience with no props. Being on the stage requires the comedian (e.g. the compere, or the actor performing the comic act) to conquer the stage with his/her personality to deliver a message to the audience in a short time, catching their attention with the first lines. The actor is missing "the fourth wall" a stage actor has: the audience cannot be ignored and thus the requirement for present tense (ibid.) is fulfilled. The jokes can exceed their expiration date, which means constant refurbishing of the repertoire. Estrada shows were adjusted to every single audience, and although there was no direct communication (ibid.) between audience and the performer besides the feedback provided by silence versus laughter, the comedian shortened or elaborated the verbal parts when needed. The main difference between estrada and stand-up is that estrada still remained a combination of different genres of entertainment (dance, song and humoresques), and the typical image of just a man and a microphone did not materialise in this form yet. Furthermore, sometimes the act required more than one actor, and quite often the actors indicate in the beginning of their routine, which role they are playing in the sketch. In radio broadcast shows, the texts were not memorised but instead read form a script unlike in live shows on TV or the stage, even though this was generally categorised under estrada as well. 


\section{Material}

For the analysis, material from two distinctive periods - Soviet and post-socialist - was sampled. Soviet material was selected on the basis of its symbolic status for its audience. It is justified to assume that popular comic texts provide us with more direct, concise access and valuable data about the main topics of these periods. The texts have become a locus of cultural memory (Assman 2006: 8). In order to pinpoint the most popular texts, recordings on YouTube of recorded/ broadcasted estrada shows were listed according to their viewing frequency. Only the YouTube popularity index was used because this Internet environment ranks first among search engines together with other Google websites (http:// www.clarksvilleonline.com/2012/05/13/comscore-releases-april-2012-u-s-searchengine-rankings/) and accounts for more than $60 \%$ of the searches performed. The three most viewed estrada videos were transcribed from this source (for links, see the reference section): Tehnikaajastu ('Technology era'; 35,064 views), Kahtlused ('Hesitations'; 21,990 views), and Kunstisaalis ('In the art museum'; 20,002 views). The original texts, written by Mikhail Zhvanetski in Russian, can be dated as follows: "Technology era" and "In the art museum" were created in the 1960s, whereas "Hesitations" is from the 1970s; exact reference to the primary source was not available; translations into Estonian originate from the 1970s.

More recent material from Comedy Estonia repertoire was recorded at ten public shows in Tartu, in the years 2010-2012. The 21,4 hours of recordings (audio, later video) were transcribed and together with the recordings will soon make up a database of early stand-up in post-Soviet Estonia. As we aimed at describing the most common topics and the role of the comedian as the mediator of these topics, the analysis will focus on the narratives or jokes that were characteristic of the comedian's routine or most popular examples of it in either period. Although it is not the focus of this analysis, I will briefly name a few dilemmas that the audience faces when a typically English-language genre meddles in an unexpected area, that of Estonian-language performance, relying on the second part of the material.

Content analysis was used for locating the main issues in the sketches via tagging the material topic-wise in a qualitative analysis programme QDA Miner.

\section{Analysis and discussion}

\section{Soviet estrada}

The background of the estrada was set by the absurdness of the Soviet rule and the daily trifles. The genre made use of all its shortcomings in an allusive, 
nonetheless officially acceptable way. This became very popular: after Estraadistuudio ('Estrada studio'), initiated in 1963, began to seek new talent for the estrada department at the Estonia Philharmonics, an enormous number of shows (ca. 4,500 in 40 years) plus an equally large amount of performances at private events like sauna parties, weddings, etc., were presented to the audience. Recorded entertainment - radio, TV and the record industry - soon followed; these were recorded in front of live audiences. Tickets to the recordings were so valuable that they even acted as currency in buying deficit goods (Eino Baskin in an interview, EPL 20.06.2009). Actors remained the same: the most famous comedians of that time include Eino Baskin, Sulev Nõmmik, Ita Ever, and a number of others. The repertoire consisted of both translated material and original sketches.

\section{Topics}

In the light of such popularity and even mythologisation, the comedians were under great pressure to address relevant topics in their new routines. The most popular of these are still remembered as tokens of cultural memory. The most frequent topic in these sketches is Soviet daily life, above all the shortage of food and other essential commodities. In the following extract, the performer starts with an exaggerative statement, listing everyday commodities that have become hard to obtain, and then twists his statement by saying that he is actually storing water, which is even more elementary for everyday existence (Kahtlused, performed by Eino Baskin):

"I have all kinds of commodities at home! Absolutely everything. My bathtub is full. I have groat, grain, rice, semolina, sugar - my tub is full! Of water, water, water, water! [laughter] What were you thinking? Water! [laughter] Maybe they'll take the water away! [loud laughter, clapping] It's better to have it, when you are allowed to. I asked, and they allowed me. [laughter]"2

(http://www.youtube.com/watch?v=rHrzkKkYMDk\&feature=related)

An almost equal target of mockery is the image of the Soviet official responsible for absurd situations, as in the following sketch where a rather dim-witted and ignorant Soviet official is sent to Paris to demonstrate a new technical invention at an international exhibition (Tehnikaajastu, performed by Eino Baskin):

"It was crowded! And everybody ta-talking pure French. In-in-intelligent people. They know fo-foreign la-languages. [laughter] So, I held a speech. I spoke in pure French - through the translator of course - I said Mes-

\footnotetext{
2 Translations from Estonian here and below by the author (LL).
} 
sieurs et Madames, I said - c'est la vie! I said that three times. C'est la vie, c'est la vie, c'est la vie. I also said boeuf à la tartar, [laughter] salad olive, boeuf strogonov! [laughter]"

(http://www.youtube.com/watch?v=BaalZCfgVO0\&feature=related)

Of course, political statements had to remain carefully veiled, but the "trick" was to sneak them in, even if for a short while, thus risking one's work and future. Sometimes, the use of politically improper texts was legitimised by their earlier publication in another Soviet socialist republic beforehand.

Nevertheless, a skilful comedian was known for making political statements in an indirect way, and this was partly what drew the audiences (Kahtlused):

"A note was hanging on the front door. And it said that there would be no hot water for three days. It's funny - there had been no hot water for two months already, and now they take it away for three days. [laughter, clapping] So I asked the ones who had put the note there what this was all about, and they said that the problem was in the system...: [long pause, hesitant laughter] the water pipes are blocked, the tubes are rusty, now they use the compressor to fix it, and in a few days it will be working again. [laughter]”

Note the long pause after the comedian has uttered the word "system", which, in this context, could mean the political system. There is some scattered hesitant laughter, as if the audience is shocked, but the relief arrives when the performer keeps talking about the congestion in the plumbing that has to be removed. In another section of this sketch, it is also the unsaid that makes people react (Kahtlused):

"I have a petroleum lamp with two extra glasses. Wick, wick... I have wick. Oil-stove - uff-uff-ff-ff [laughter] - remember? You remember, but I have it, [laughter, clapping] barrel of petroleum, box of soap, bucket of penicillin, four hundred meters of bandage, six kilograms of cotton pads, two liters of iodine... But maybe suddenly, on one beautiful day, they will come... [long pause, laughter, clapping] Bad weather! Bad weather will come! [long laughter]”

The hint here is obviously about the repressive organs who in the 1940s deported all those who had more possessions than usual, labeling them kulaks and accusing them of treason against their homeland and communism. The unspecified "they", combined with the long pause, makes a perfect political punch line.

The comedian usually took on different personas, thus becoming a "negative exemplar", a marginal figure of an unintelligent boss with a stutter, a paranoid neighbor, or a drunkard. The last extract is from a sketch that depicts a drunkard talking about his experience in an art museum where he was trying 
to "have a cultured rest", i.e. drink vodka - and eat some fish to have something in the stomach (Kunstisaalis, performed by Eino Baskin):

"I told her quietly, I told her intelligently: "Stop hissing, you white rodent. Stop hissing! [laughter] You see I have half a liter [vodka] and I don't have a glass. [laughter]" So I took a little vase from there - what bad things can happen, it's made of iron. [laughter] - "You should be ashamed of yourself! You should be ashamed of yourself! The vase is a $19^{\text {th }}$ century Biedermeier!" - "You are a proper biedermeier yourself!" [laughter]" (http://www.youtube.com/watch?v=H2irYp-dv7M)

\section{Post-socialist: Comedy Estonia}

Comedy Estonia presented their concept to what was initially a very small auditorium of a maximum of 30 people in a miniature pub in Tartu called Möku. The first show at Möku started out with the MC outlining the genre rules, including the basics of interaction with the audience:

"A bit of audience participation then, maybe we should start with that. I think we are at the right point now for a group "Boo" - can we just try that all together as this show has been quite shit so far. ["Booo!"] Yeah, can we all now go together "Boo!" ["Boooo!"] Super! Thanks very much. [laughter] And we use this sign for boos. Excellent. Fantastic.”

(the MC, Eric, 28.08.2010)

The show was welcomed warmly and the word got out fast. More shows soon followed on a slightly bigger scale, although monthly small-venue shows in Möku which provided an open mike for novices continued to exist. Gradually, a business evolved around the initially underground movement as the same artists started standing up at larger shows and private gigs as well as inviting some big names of international comedy (recently, Dylan Moran) to perform in Estonia. Parallel to that, shows moved to Tallinn where the potential audience was bigger, adding e.g. Club Privé to the list of venues. Comedy Estonia has stated that remaining true to a few locations is good for the image ("At the current time, we have a few venues and we work closely with them to establish them as places where people come to see comedy — we don't just perform in any club around town", Zezeran 22.02.2012), although the idea of introducing stand-up to various audiences around Estonia implied touring the shows around, much like Soviet estrada was performed in culture houses, i.e. a network of multi-purpose cultural venues mostly in the more rural areas. 


\section{Topics}

For a foreigner doing stand-up in front of a local audience, the first and most obvious choice is to turn the listener's laughter against their own funny or peculiar ways, because these are the traits they recognise, but perhaps cannot point out by themselves. So, the first and most obvious choice of a topic is cultural differences that the foreigner has had to come to terms with. The marginality of the "negative exemplar" is also visible here - it is the "other" who is presenting his point of view to the majority, the Estonians:

"Inhaled speech. [long pause] This is one of the best idiosyncrasies that I love about Estonians. Now people have been talking about exhaling before. But let me tell you: for every exhale, there is an opposite and equal inhale. [scattered laughter] It's true. And if you're lucky, sometimes you'll hear people say it in the middle of a sentence. It's like the thing that they're talking about is so important that they forget to breathe. "Oh yes, I brought this dress the other day and it was [inhaled] >absolutely gorgeous<!" [laughter] But on rare occasions, you'd hear what I would call a full lung reversal [laughter], where they speak normally, inhale and speak normally again all in the same sentence. "Come on, honey, try on [inhaled] >this dress here< I want to see if it looks good on you." [laughter throughout] But under rare occasions the whole sentence... is inhaled. [laughter] So much so, that at the end of the sentence there is no more room in the lungs. They can't squeeze any more air in there. But they keep talking [laughter] ">Oh yeah I got a khakhhakh [laughter] khkhkh [more laughter] $k h k h<$." (Stewart, 08.06.2010)

Another example from the repertoire of another Comedy Estonia founder Eric Seufert is relevant as he backs the same subject up in a show from a couple of nights before, and to the even greater enjoyment of the audience, as judged by the intensity of audience reactions:

"The service can be bad in Estonia. You know, one thing you sort of get used to is... I think Estonians as a nation have sort of perfected the art of the passive aggressive sigh. [laughter; long sigh, more laughter] When I first moved here I tried to open a bank account and I'd been studying Estonian for about a summer so I wanted to do the whole process in Estonian. And it was taking forever and this huge line built up behind me. And it literally sounded like I was in the waiting room at an asthma treatment ward. Like fifteen people going "Hhhhhh." [laughter] I think Estonians have the lung capacity of a Sherpa. I'm surprised why Estonians don't lead expeditions to the top of Mount Everest. Eyes on their feet, not mak- 
ing eye contact with anyone, they get to the top, and make some sarcastic comment. [long laughter, clapping] "That was fast... Hhhhhhh."”

(Eric, 04.06.2010)

Both of these routines laugh at the peculiar ways of communicating that the Estonians practice. This is not at all surprising that a number of the first shows visited this topic often. Face-to-face communication is the source of first impressions. In jokelore, a number of old joke tales (Schwanks) depict linguistic differences, and this has been the basis for stupidity jokes for longer than can be remembered (see also Davies 1990). However, after the first impressions about linguistic encounters have settled down, more profound insights can take their place. Stewart shares an experience that he first delivers as a cultural difference, but eventually develops it into a sexual joke:

"If there's one thing that I've learned then that is when Estonians go to the cash register to pay for their groceries, they love to use the divider between different customers. And I've been trying to figure this out for years why is this so, until the other day [chuckles] I went to the grocery shop and went to the cash register to pay, the guy in front of me was basically just waiting for the cashier to take his last item... it was... I don't know... a carton of eggs. And I was just there for a snack, I had like... a banana, and I put it on the very back end of the conveyer belt. We had a good meter between our goods there [laughter], but I did not put a divider and this guy didn't like that at all. [laughter] He looks here... and he looks at the banana... looks at me... stares at me for a minute... and he couldn't take it! He grabbed the divider and slammed it down. [laughter] And after all these years trying to figure out what this is, I just then realised it: in Estonia, you have to have a divider between one man's eggs and another man's banana. [long laughter]" (Stewart, 07.09.2010)

Some peculiar aspects of the Estonian lifestyle or the country itself, besides the Estonians, are sometimes made fun of (in the following example, the tradition of celebrating Jaanipäev, the Midsummer night, with much drinking in the countryside):

"The day after Jaanipäev I was feeling a bit suicidal [laughter]. So I went on a drive. Actually, I am quite surprised that we've got so many people here [on the show] because this week Estonia is closed. For all we know we could have been invaded by Latvia. Nobody noticed until Monday morning when everybody gets back from the countryside. [chuckles] For five days the only thing standing in the way of Estonia's enemies are the fucking mosquitoes! [laughter]" (Andrei, 04.06.2010) 
As time goes by, the imaginary boundaries between outsiders - the foreign performers - and the in-group - the local Estonian audience - become more and more fuzzy. The new topic here is the experiences of a well-assimilated foreigner living in Estonia. At times, references to deeply Estonian cultural phenomena that foreigners usually would not have the faintest idea about sneak into the routines. The following one-liner by Stewart combines two items of in-group knowledge to make a kind of pun that can probably be understood only by an Estonian:

"This is very embarrassing but... For years I thought that the most popular literature in Estonia is a 15-volume collection of love poetry devoted to a woman named Ene. [laughter, clapping]"

(a popular woman's name in Soviet Estonia, and also abbreviation ENE, or Estonian Soviet Encyclopaedia, which was the most common sight on every Soviet bookshelf) (Stewart, 10.04.2012)

In this joke, he refers to himself as someone who embarrassingly enough was not aware of the latter connotation, but has by now eventually got it and is now entitled to become one of the in-group, the audience. Nevertheless, knowing that Ene is an Estonian female name is an equally cultural piece of knowledge that you would not expect from an American coming from South Carolina.

The degree of acculturation is also visible in statements or routines that imply changes in the stand-point of the foreign comedian who used to be just an American/Australian, but has now distanced himself from the former in-group, that of his country, and judges them from the point of view of the local, Estonian audience, for example, in a routine Stewart performed about Americans not knowing where Estonia is:

"Whenever I talk to Americans they'll always ask me so where do you live, and I'll say Estonia, and there's always this... awkward pause. They are not quite sure what I'm talking about. Now I don't want to help them along either, I just kind of let the pause happen. - "Where do you live?" - "Estonia." [very long pause, laughter] - "And where is that?” - "Oh it's just next to Latvia. [laughter]” (Stewart, 16.08.2011)

By going through Stewart's repertoire, we see how a foreign point of view turns into an insider's standpoint as he gets to know his audience better. He is not a foreigner any more; instead, there is a sense of "us" in between his punch lines. The foreigner's first encounters and points of view derived from that have worn out, and via interaction with the audience a new identity is constructed. Stewart is not necessarily one of the Estonians, but he is most certainly an essential part of the stand-up scene which forms an in-group of its own right: a multicultural, stand-up literate, self-conscious group of people. During the show, they 
accept his authority to express opinions about things they feel similarly about; the audience as a group is ready to laugh at whatever observation he chooses to form into a joke. He has become familiar to them, and the personality he adopts on the stage works well for him. The audience might feel they know him as a friend, along with his wife and the rest of the family; he has become one of them. The disposition to laugh is backed up by affection for the performers, or as Woody Allen has said: "[The audience] wants to like the person and find the person funny as a human being. The biggest trap that comedians fall into is trying to get by on material." (from Nachman 2003: 546).

Numerous insights into daily news and politics become frequent especially at the end of the two-year period that was analysed (e.g. installing speed cameras on the Tallinn-Tartu road, having had a Polish plane emergency landing in Tallinn's water reservoir), or rumours about Estonian politicians:

"What do an ambulance car and Katrin Siska have in common? - A fat old man has taken a ride in both of them. [laughter] I did the same joke on Vabaduse Väljak in Tallinn just next to the Tallinn mayor's office and I got offered a billion Kroons in unmarked bills to start telling Ansip jokes instead. So: Knock-knock! (audience: "Who’s there?”) Ansip (“Ansip who?”) That's what everybody will be saying after the next elections."

(firstly referring to the rumours of Kartin Siska, a young singer and new member of the Central Party, and Edgar Savisaar, the mayor of Tallinn and leader of this party, having an affair, and secondly, to the political competition between Edgar Savisaar and Andrus Ansip (prime minister) and leaders of the Center and Right-wing parties) (Andrei, 16.08.2011)

However, talking about politics is not by far as frequent as one could assume by the connotations the genre has in the Anglo-American context. Here, the Estonian part of the audience is usually left uncertain about whether to give the foreigner a license to talk about internal politics, whereas the foreigners in the audience are generally not interested in or familiar with the subjects. The safest way to make the audience laugh at Comedy Estonia's stand-up events is to use the experience of a foreigner observing the country and its local inhabitants, as this works for both sections of the audience.

\section{Comparison of popularity among audiences}

The next question is how the shifts and changes in the nature of comic performance, performers and their topics have affected the patterns of popularity of the genre. Estrada in Soviet Estonia was born out of a necessity to distract the crowd from more subversive actions. In the words of the first editor of the radio 
entertainment programme RAMETO (short for Raadio Meelelahutussaadete Toimetus, Radio Entertainment Office) Priit Aimla, this was a political attempt to indirectly ban church-going (interview with Priit Aimla, Sept 8, 2005). The shows became popular very quickly and a constant need for material forced the editors to translate texts from comedy writers from inside the Soviet Union. The fact that most of the texts were of Russian origin did not affect their positive reception. Further testimony to the popularity of the genre was its status as a Western phenomenon, thus subject to censorship. The genre was officially accepted but severely controlled, and every show had to be given a green light before being allowed to play and/or tour. While estrada artists were highly admired by the audiences and their texts or songs quickly became folklore, they were frowned upon by the Soviet authorities and official media (interview with Rein Klink, EPL 13.02.2001). The stigma of Westernisation of the estrada shows became even stronger after the 8th plenum of the Central Committee in 1951 that banned elaborate plays, satire and double meanings in favour of simple didactic performances for proletarians. This, in turn, fostered people's ever-growing affection for the nonconformist genre. One of the first shows of the newly established estrada club staged was "Kuu peale" ('To the moon') by Valdo Pant. The actors of that show have recalled a particular scene that was woven in the text as an anti-regime statement ("Kes väikese või suure linnuga, tähtsaid asju ajavad võrdse innuga" ('Those with more or less bats in the belfry / take care of important things most eagerly')) directed against the Soviet officials, but the hint went unnoticed during control rehearsals (interview with Lia Laats, Postimees 12.04.2000). In addition to that, it was not uncommon that estrada actors were imprisoned for anti-Soviet propaganda and later suffered sanctions and repressions exercised by the political power (Möldre 2010). Sometimes this came down to the level of urban legends: rumours of Mari Möldre's perpetual imprisonment due to her bold statements constantly emerged and many comedians secretly became heroes to the crowds.

As Lõhmus (2012) shows, stupidity and social vices such as greediness and arrogance were often mocked, and this was welcomed very warmly by the audience: "The status of broadcast humour was very high [...] the shows were recorded in different locations all over Estonia (collective farms, clubs, work collectives, etc.) which brought the jokes closer to the auditorium and at the same time this environment was the inexhaustible source of the humour itself." The evergreen state of some of the comic texts from the 1970s and 80s prove that the texts have remained significant to the people, although they symbolise something else now: they are loci of nostalgia and cultural memory, a counterpoint for the self-identification of a nation (see Chłopicki 2012). The most important aspect that should be stressed is that Estonian estrada united the nation. As Lõhmus puts it, being interested in the genre "was a collective habit, situative, and at the same time diachronic." The official censorship involuntarily helped 
to increase its popularity, motivating people to collectively listen to / attend the shows and constantly search for the hidden subversive element in the texts.

In the case of Comedy Estonia, the pattern for achieving popularity has been different from the start. There was no cultural need for humorous venting of sentiments as in the Soviet period. However, there was a void that was waiting to be filled, because there was not much comedy on stages at the end of $1990 \mathrm{~s}$ and the beginning of the $21^{\text {st }}$ century. The beginning was a success: "When 170 turned up, we knew we were on to something. Our shows are regularly sold out each month" (interview with L. Zezeran, 22.02.2012). The ways of informing the potential audiences of their activities have been highly informal, personal and based on communication networking. Although printed posters were also used for advertising, word of mouth and other informal channels (recently their Facebook fan page where they have slightly less than 4,000 fans) were and have remained the most important ways for informing the potential audience about upcoming events. This adds an alternative or underground sense and is essential in constructing a strong in-group identity, and fostering a devoted audience.

Comedy Estonia uses the Western model of doing stand-up, and many of the artists are invited from Scandinavia or other parts of Europe. Nevertheless, as the leaders of the stand-up movement in Estonia have stressed, the initial goal of Comedy Estonia was not to impose Western stand-up comedy on Estonians, but to develop stand-up comedy from an Estonian perspective. As a one year anniversary celebration, Comedy Estonia leaders put together the first Estonian language show where their more or less Estonian-speaking members (Eric Seufert, Stewart Johnson, Andrei Tuch, Keiu Kriit and Janika Maidle) performed at a densely packed Wilde pub in Tartu. The Estonian language shows have not become regular yet, but interesting developments await in this area - it is yet to be seen if Estonians are ready for Estonian language standup or will it fall flat due to a number of reasons (e.g. the audience is primed with English-speaking acts they have seen on YouTube or other channels; in a comment to the Estonian-language stand-up tour, an anonymous commentator said "Estonian-language stand-up comedy? Now that is something. It's from the same category as "innocent granny"” (Roosaar, 05.05.2012).

So, does the cultural context and foreign influences within that foster the use of certain topics, and how does that affect the reception of the genre analysed in this article? The choice of topics in both periods was affected by the origin of the text and the performer alike. In the case of Comedy Estonia, the routine presented by its author represented the onlooker's view on Estonian society, the country and its inhabitants. They were marginal in terms of providing a generalised, alienated account of the local inhabitants, and to top it, presenting their material in English. Only gradually did their routines start to include insider's insights (e.g. sketches about Estonian politics). Estrada actors were Estonians, but they distanced themselves from the mainstream in their open 
accounts of the absurdness of daily life; they were the outsiders, the jesters who could voice the criticism denied to ordinary people. The rumours about comedians being imprisoned for their utterances on the stage strengthened this image even further. In either Soviet or the present-day case, Mintz's (1985) idea about the "negative exemplar" works for understanding the performer's stance. The part played by the performer allows for verbalising the unsayable in both periods, which in turn is the cornerstone of the performer's popularity. The topics, of course, are contextual and thus differ in those two distinct periods, but more importantly, the popularity of the comic sketches is not based on the topics; instead, it is the role of the performer, defined as the "other" to the audience, allowed to utter statements that the audience refrains from or is forbidden to say. The popularity of the Soviet estrada rose to incredible heights and embraced the whole nation (if not more, considering that the routines were performed with great success in many countries and languages inside the Soviet Union). Compared to this, Comedy Estonia has worked at its popularity with slightly different methods in a completely different social context - it aims at creating a steady fan club by fostering its fan's self-identification as a comedygoer and takes the first steps in introducing Estonian-language stand-up, but its popularity is still nothing like the Soviet estrada was at its heyday. The main difference probably lies in the significance of the genre to the audience, as it was more than mere entertainment during the Soviet era. A devoted audience is created through fostering a feeling of solidarity and the pleasure of laughing together, which, as has been confirmed, is one of the basic motives that draws people to frequent stand-up events (Locker \& Myers 2011: 181-182).

\section{Conclusion}

This comparison informs us about what makes a genre popular and accepted it is largely not the topics that the comedian addresses in the routines, but the wider societal context that prepares the audience and suggests its reactions. The predecessor of stand-up, Soviet estrada, was very popular in the 1970s and 80 s, and regardless of its largely foreign origin, it was well-suited for engaging in an intense dialogue with the audience who was starving for social and political criticism. Comedy Estonia, on the other hand, is eager to be flexible and provides their fans with Western comedians as well as is constantly looking out for Estonian talents, but their attempts may stumble upon the relatively limited significance of the texts when it comes to commenting on the domestic politics of Estonia and other local issues. Comedy Estonia's strength lies in the viewpoint of the "other", but in trying to perform in Estonian or talk about Estonian internal politics, they strip themselves of the useful persona and 
may find they are left with nothing. Besides, the global approach (i.e. using only topics understandable to cross-cultural audiences) works for a while, but as the material becomes more localised and specific, then after a number of shows the foreign performers, having recited all their funny encounters with the locals, reach a dead end.

The analysis develops our understanding of stand-up comedy from the perspective of how the popularity of a genre interacts with the choice of topics and the wider societal context surrounding these choices. The present study would have benefitted from a larger corpus of examples of the Soviet estrada. Nevertheless, even a small sample suggests that the most popular texts were (and still are) funny not because of the topics only, but of the role of the Sovietera comedian, the stigma of Westernisation and a number of other contextual factors. For future studies, more interviews with performers and audiences from either period should be conducted in order to develop this thesis further.

\section{References}

Assmann, Jan 2006. Religion and cultural memory: Ten studies. (transl. by Rodney Livingstone) Stanford: Stanford University Press.

Chłopicki, Władysław. Stand-up tragedy in Poland? In: L. Laineste \& D. Brzozowska \& W. Chłopicki (eds.) Estonia and Poland. Creativity and tradition in cultural communication, Vol. 1. Tartu: ELM Scholarly Press, pp. 91-110.

Davies, Christie 1990. Ethnic jokes around the world. Bloomington: Transaction Publishers.

Double, Oliver 2005. Getting the joke: The inner workings of stand-up comedy. London: Methuen.

Interview with Eino Baskin 2009. Ma olen seda naeru nii palju näinud. [I have seen so much of laughter.] Eesti Päevaleht, 20.06.2009. http://www.epl.ee/news/kultuur/einobaskin-ma-olen-seda-naeru-nii-palju-nainud.d?id=51171769, last accessed in March 2012.

Interview with Lia Laats 2000. Poole tunniga väljavilistamisest ovatsioonideni. [From booing to ovations in half an hour.] Postimees, 12.04.2000. http://arhiiv2.postimees. ee:8080/htbin/2art?/leht/00/04/12/uudised.shtmXneljateistkymnes, last accessed in March 2012.

Interview with Louis Zezeran 2012. The ex-pat revolutionaries of Estonia. Splitsider 22.02.2012. http://splitsider.com/2012/02/the-ex-pat-revolutionaries-of-estonia/, last accessed in March 2012.

Interview with Priit Aimla 2005. Kutse "Meelejahutaja" lindistusele oli defitsiit. [Invitations to "Meelejahutaja" recordings were scarse.] Õhuleht, 8.09.2005. http://www. ohtuleht.ee/180660, last accessed in May 2012. 


\section{Liisi Laineste}

Interview with Rein Klink 2001. Estraadiosakond loodi 60 aastat tagasi raha pärast [Estrada department was created 60 years ago for the money.] Eesti Päevaleht, 13.02.2001. http://www.epl.ee/news/melu/estraadiosakond-loodi-60-aastat-tagasi-rahaparast.d?id=50866375, last accessed in March 2012.

Jelavich, Peter 1996. Berlin cabaret. Cambridge, MA: Harvard. University Press.

Koziski, Stephanie 1997. The standup comedian as anthropologist: Intentional culture critics. In: J. Boskin (ed.) The humor prism in 20th century America. Detroit: Wayne State University Press, pp. 86-114.

Lockyer, Sharon \& Lynn Myers 2011. "It's about expecting the unexpected”: Live standup comedy from the audiences' perspective. Participations: Journal of Audience and Reception Studies, Vol. 8, No. 2, pp. 165-188.

Lõhmus, Maarja 2012. Political correctness and political humour in Soviet Estonia and beyond. In: L. Laineste \& D. Brzozowska \& W. Chłopicki (eds.) Estonia and Poland. Creativity and tradition in cultural communication, Vol. 1. Tartu: ELM Scholarly Press, pp. 139-158.

Mesropova, Olga 2008. Private space of the public stage: Marriage in Russian stand-up comedy in the 1990s. In: O. Mesropova \& S. Graham (eds.) Uncensored?: Reinventing humor and satire in post-Soviet Russia. Bloomington: Slavica Publishers, pp. 219-231.

Mintz, Lawrence E. 1985. Stand-up comedy as social and cultural mediation. American Quarterly, Vol. 37, No. 1, pp. 71-80.

Möldre, Mari 2010. Eesriie avaneb. [Curtains open.] Tallinn: Eesti Päevaleht.

Nachman, Gerald 2003. Seriously funny: The rebel comedians of the 1950s and 1960s. New York: Pantheon.

Purcell, Darren \& Melissa S. Brown \& Mahmut Gokmen 2010. Achmed the dead terrorist and humour in popular geopolitics. GeoJournal, Vol. 75, pp. 373-385.

Roosaar, Mart. Eestikeelne stand-up komöödia jõuab Pärnusse. [Estonian-language stand-up reaches Pärnu.] Pärnu Postimees, 05.05.2012. http://www.parnupostimees. ee/830922/com/eestikeelne-stand-up-komoodia-jouab-parnusse/, last accessed in May 2012.

Stebbins, Robert A. 1990. The laugh-makers: Stand-up comedy as art, business, and life-style. Montreal and Kingston: McGill-Queen's University Press.

Trilljärv, Aleksander 1919. Lõbus näitelawa: monoloogid, deklamatsioonid, laulud, kupleed, kõned, westelood, soolonumbrid iseloomukujutustest ja mitmesugused naljakad ettekanded. [Comedy stage: Monologues, declamations, songs, couplets, speeches, stories, personifications and various funny acts.] Tallinn: G. Kalla.

\section{Estrada sources on YouTube}

http://www.youtube.com/watch?v=rHrzkKkYMDk\&feature=related, last accessed in May 2012.

http://www.youtube.com/watch?v=BaalZCfgVO0\&feature=related, last accessed in May 2012 .

http://www.youtube.com/watch?v=H2irYp-dv7M, last accessed in May 2012. 